John Carroll University Carroll Collected

Theology \& Religious Studies

$1-1992$

\title{
Divine folly : being religious and the exercise of humor
}

Doris K. Donnelly

JohnCarroll,ddonnelly@jcu.edu

Follow this and additional works at: http:// collected.jcu.edu/theo_rels-facpub

Part of the Christianity Commons

\section{Recommended Citation}

Donnelly, Doris K., "Divine folly : being religious and the exercise of humor" (1992). Theology \& Religious Studies. 64.

http://collected.jcu.edu/theo_rels-facpub/64

This Article is brought to you for free and open access by Carroll Collected. It has been accepted for inclusion in Theology \& Religious Studies by an authorized administrator of Carroll Collected. For more information, please contact connell@jcu.edu. 


\title{
DIVINE FOLLY: BEING RELIGIOUS AND THE EXERCISEOF HUMOR
}

\author{
By Doris Donnelly \\ "Jesus, for one, was witty, unpredictable, fully alive, and a person who delighted in, celebrated with, and was open to \\ surprise.... [I]t is safe to say that divorcing humor from religion is potentially destructive of true religion. Even when \\ the separation is done with the best of motives, or in ignorance, the results are disastrous because we rob ourselves of \\ the lightness and freedom necessary to notice and then to adore God." \\ "Life is serious all the time, but living cannot be. You may have all the solemnity you wish in your neckties, but in \\ anything important (such as sex, death, and religion), you must have mirth or you will have madness. "* \\ G. K Chesterton
}

A curious custom in the Greek Orthodox tradition gathers believers on Easter Monday for the purpose of trading jokes.2 Since the most extravagant "joke" of all took place on Easter Sunday - the victory, against all odds, of Jesus over death - the community of the faithful enters into the spirit of the season by sharing stories with unexpected endings, surprise flourishes, and a sense of humor. A similar practice occurs among the Slavs, who recognize in the resurrection of Jesus of Nazareth a joy that it is Jesus who has the last laugh.

The response of the Greeks and the Slavs seems to be most appropriate, and it is disappointing that these practices strike our contemporary mindsets as a little odd. Most mainline Christian congregations, after all, do not celebrate Easter quite this way.

\section{I}

Something has gone wrong with our perception of the alliance between being religious and having a sense of humor. Three elements apparently have contributed to a dimming of the connection between these two areas and have solidified into bona fide obstacles to the critical and desperately-needed exercise of humor. Pervasive and formidable, each of these obstacles deserves a word of explanation.

The problem begins with persons who perceive humor as unworthy of the majesty of God. For some, humor is undignified, frivolous, and unbecoming of the grand sphere of the divine, which either uneasily accommodates the informality of humor or rejects it outright as unacceptable.

Several years ago, Umberto Eco's powerful novel, The Name of the Rose, reflected this way of thinking by introducing the villainous monk Jorge, who poisoned anyone who came upon the one book in the monastery library that proposed that God laughed. The investigator who uncovered the malice asked Jorge the question on the reader's mind: "But what frightened you in this discussion of laughter? You cannot eliminate laughter by eliminating the book." Jorge defended himself by claiming: "Laughter is weakness, corruption, the foolish- ness of our flesh [but] the function of laughter is reversed fin this book]: It is elevated to art, the doors of the world of the learned are opened to it, it becomes the object of philosophy, and of perfidious theology." 3 
From Jorge's point of view, the possibility of anyone learning anything from laughter could not be tolerated. "I accept the risk of damnation," Jorge boasts. "The Lord will absolve me, because He knows I acted for his glory." 4 Presumably, as a devoted bibliophile, Jorge could not bring himself to eliminate the book itself which, after all, would have prevented anyone from discovering it. Apparently, eliminating people was a less serious offense! The response of the Greeks and the Slavs seems to be most appropriate, and it is disappointing that these practices strike our contemporary mindsets as a little odd. Most mainline Christian congregations, after all, do not celebrate Easter quite this way.

Few would go to the extremes Jorge did, of course, but that same repressive spirit is apparent among those who reckon theology and worship to be sacrosanct spheres where laughter and humor are out of place. Perhaps, they confuse humor with comic books and one-liners and miss its depth and insight into human nature. Reinhold Niebuhr, for one, reminds us that "humour is, in fact, a prelude to faith, and [that] laughter is the beginning of prayer." 5

Jorge is an example of someone who felt that the crudity and baseness of humor was inconsistent with the elegance of the Creator God who needed to maintain all the distance possible from created humanity. What drove Jorge to desperation, among other things, was the thought that God and humankind could become, if not equals, at least friends through the familiarity humor engenders. A universe where men and women could appreciate the divine folly of God taking on human nature in the mystery of the incarnation was a scandalous consideration for Jorge, and it still is for the many who think like him.

The second obstacle to the exercise of humor is that laughter is not easy to come by in circles where people speak for God and not to God. Prime culprits are those in authority, like parents and clergy and theologians, who too often speak with absolute confidence concerning what God wants, when God will reward, whom God loves, how God will punish, what God thinks, and how God feels.

The Jewish experience of God is frequently (and mercifully) of a different sort. A familiarity with God uncommon in mainline Christian circles is widely apparent in Judaism, along with the acceptance of human emotions before the Deity. Jews have a long history of weeping, moaning, and raging, as well as rejoicing before Yahweh, while the liturgical behavior of Christians seems, by comparison, to be consider- ably more polite and restrained. The conversation of the Jew with God was precisely that: a conversation, with a give-and-take rarely found, if not entirely unheard of, in the Christian way of relating to the Creator.

For example, there is the story of the atheist grandmother, claiming Jewish cultural (if not religious) roots, who took her beloved five- year-old grandson to the beach. Decked out in his sun suit and hat, and equipped with his pail and shovel, the little boy played happily near the water, building castles and moats. When the grandmother dozed, the grandson was suddenly caught in an undertow and was soon nowhere in sight. The frantic 
grandmother called for help, but there was no one else on the beach. Figuring she had nothing to lose, she fell to the ground, raised her arms to heaven and prayed, "God, if you exist, if you are there, please save my grandson. I promise I'll make it up to you. I'll join the Hadassah; I'll volunteer at the hospital; I'll join the men's club, the women's club, whatever makes you happy." And suddenly a huge wave tossed the grandson on the beach at her feet. The grandmother bent over to hear his heart beating, she noticed color in his cheeks, his eyes opening, but she appeared upset. Bringing herself to full height, and with hands on her hips, she wagged her finger at the sky: "He had a hat, you know!"6

Humor is possible in this situation only because the grandmother speaks to and not for God. The repartee is down-to-earth. Fear and domination are missing from the scene. The grandmother knows her place, and God's. It may appear as though she is overstepping her bounds, or that she is disrespectful, but the truth is that it is the person who speaks for God who shows disrespect. The grandmother is simply being a grandmother. And in typical Jewish fashion, the God in the story is personalized. God is someone who can be berated and cajoled because God is very much part of the family. Speaking to and not for God is a helpful warm-up exercise which enables the acquisition of a sense of humor.

Still, a third obstacle that explains the flabby condition of many un-humorous Christians is the pervasive inability to uncover humor in the events recorded in Holy Scripture, as the Greeks and Slavs did, especially in the life and death of Jesus of Nazareth. Years of conditioning have rendered the Scriptures as predictable and innocuous stories in which serious people speak in a language filled with moralisms and legalisms, lacking fun and surprise. The dangerous consequence of reading the Bible this way is that the Creator God and, by extension, Jesus Christ, become humorless beings incapable of enjoying a joke. And so do we as their disciples.

Since the facts support a different interpretation-Jesus, for one, was witty, unpredictable, fully alive, and a person who delighted in, celebrated with, and was open to surprise - it is safe to say that divorcing humor from religion is potentially destructive of true religion. Even when the separation is done with the best of motives, or in ignorance, the results are disastrous because we rob ourselves of the lightness and freedom necessary to notice and then to adore God. Although it may appear otherwise, it is lightness that allows us to appreciate God; seriousness and heaviness tend to force us to concentrate on ourselves. "Seriousness implies gravity," one wise scholar proposed. "Gravity is the force that pulls all things to the center. It is what keeps us from flying. It is the opposite of levity, which is the force that raises things and makes them light. Religion is supposed to free the spirit from gravity, raise it, lighten our loads, and enlighten our minds."7 We all lose when this does not happen.

Fortunately for us all, a new lens is being fitted onto biblical interpretation that highlights a different way to look at salvation history. Many distinguished biblical scholars are finding humor as a key to unlock the meaning of the holy writings.8 Some focus on the parables, while others are unearthing a humorous perspective in the miracle stories. Robert Fowler, for example, attempts to show that Mark's use of miracle stories mocks the quest for power among the disciples as well as among contemporary readers.9 And following the lead of the anthropologist Mary Douglas, who held that "the joke affords 
opportunity for realizing that an accepted pattern has no necessity,"10 Jonathan Z. Smith sees the unpredictability of the miracles as an expression of transcending fate and destiny so ingrained in much Mediterranean thought.11

The yield of this kind of scholarship is that God and many of the personalities in the Scriptures emerge in full color with refreshing perspectives never before seen by most of us. We see Jesus as one who used irony, played with words, appreciated and exercised wit, and engaged in the cosmic surprise (or divine incongruity 12) which we call the incarnation.

Some people think the most important question to ask is: "Did Jesus tell jokes?" A far, far better question is: "Did Jesus have a sense of humor?" He did. No matter what the Jorges of the world would want us to believe, there is a disabling consequence associated with not finding humor in the gospel when it is there. The tragedy is that we may not only miss the message, but that we may receive the wrong message.

Doug Adams, who has spent a great deal of his time uncovering the humor of the Scriptures, 13 illustrates the dilemma and the difference humor makes in his discussion of Matthew 22:15-22, where Jesus is challenged to resolve the issue of paying monies to Caesar. Many conclude that this episode is about the separation of Christian faith from politics and the insistence of Jesus to keep money and piety in different compartments. But they may be missing Jesus' sharp humor in eluding the trap laid by the Pharisees and his clever unmasking of their hypocrisy.

Reading the passage afresh, we notice that when Jesus asks the Pharisees to produce a coin, they do so, even though a strictly pious Jew would never carry a coin bearing Caesar's image with an inscription proclaiming Caesar to be king and God. These presumed righteous citizens are thus carrying around coins that break two commandments! The behavior of the Pharisees is incriminating, embarrassing, and amusing, to say the least. Robert Funk also points out that there is no indication that Jesus returned the coin to the Pharisee. According to Funk, as Jesus proclaims the punchline"and render to God the things that are God's" - he pockets the coin and has the last laugh.14

\section{II}

We need to be very careful in defining humor because humor tends to die in the process of dissection. Elusive as it is, humor is generally understood to involve two elements: a gentle acceptance of the incongruities of life and the ability not to take ourselves too seriously. The root of the English word "humor" is the Latin umor, meaning "liquid, fluid." ${ }_{15}$ Perhaps, then, humor is something that flows within us and courses through us with the ability to refresh perspective, heal attitudes, and balance our equilibrium. The American Heritage Dictionary helpfully offers "a capacity to appreciate or understand" as a designation for a sense of humor. That may be the most helpful clue of all.

What is being understood, appreciated, and even embraced through humor are those many puzzling, curious, and mismatched events and occurrences that permeate the dailiness of existence. Comedian Woody Allen has a particular genius for pointing out 
these incongruities.16 In The Nightclub Years, he tells us that his parents' values are "God and carpeting"; in Take the Money and Run, his mother-in-law has a conversation with God about "salvation and interior decorating." The sublime and the ridiculous, or the expected and the surprise, are paired - that is incongruity. Our kindly contemplation of these juxtapositions is integral to humor.

Not all incongruities, however, are funny or entertaining. Most of us can think of tragic "incongruities" that have happened to friends or family. One such friend of mine was diagnosed with a malignant tumor in the first week of her long-awaited sabbatical. A newly married couple, eager for a baby, were told that the wife would probably never be able to conceive. Twin sons of a musically-gifted mother and father were born deaf. When we are face-to-face with incongruities such as these, then laughter or joke-telling is not an appropriate response. "To laugh at life in the ultimate sense is to scorn it," Reinhold Niebuhr wrote. ${ }_{17}$ But what is a fitting response is for each of the people involved to step back and gain the balance, perspective, and sense of proportion necessary to match up against the incongruities besetting them. In this way, Niebuhr explains, humor is a starting point in the life of faith. Religious faith offers the deep insight that the incongruities of life do not need to defeat us.18 An ultimate victory over powers that seem insurmountable is possible.

The Christian faith is so filled with incongruities (the weak inherit the earth; the foolish teach wisdom; the lame are restored to wholeness; death leads to life; a virgin gives birth; giving is a prelude to receiving) that it is hard to imagine how one could be religious and not have a sense of humor.

\section{III}

The most extraordinary incongruity of all, of course, is the incarnation: God takes on flesh and human nature. The impossible becomes possible. A king is born in a stable; a child upsets the entrenched political establishment; the savior is servant of all, rejecting privilege and status. Paul wrote about this "divine incongruity" when he noted that "Christ Jesus, though he was in the form of God, did not regard equality with God as something to be exploited, but emptied himself, taking the form of a slave " (Phil. 2:5b7a).

To no one's surprise, the history of the early church chronicles a lengthy list of heresies that denied, compromised, or confused the teaching concerning the God-man Jesus Christ. Some believers gracefully accepted and embraced the event in which God becomes one of us in all things but sin, but many did not. Furthermore, the eminent theologian Karl Rahner suggests that the identity of Jesus, hammered out at the Council of Chalcedon in 451, even now sits uneasily with many who refuse to accept the humanity of Jesus.19I am especially fond of Rahner's designation for such persons as "crypto- monophysites." This term not only tells us, I think, something about the perennial difficulty in accepting the "divine incongruity" of the incarnation, but the clever turn of phrase may also reveal something of Rahner's own sense of humor as well.

The long and the short of it is that a sense of humor may well be a sign of God's presence 
in the life of a believer, but it is a gift always in jeopardy of being lost. Perhaps that is why many have prayed for it, prizing it above all other gifts. Danish philosopher S0ren Kierkegaard (of all people!) was one who claimed he could not live without humor. On one occasion, he wrote of a dream he had when he was young:

\footnotetext{
Something marvelous has happened to me. I was caught up into the seventh heaven. There sat all the gods in assembly. As a special grace, there was accorded to me the privilege of making a wish. "Wilt thou," said Mercury, "wilt thou have youth, or beauty, or power, or long life, or the most beautiful maiden, or any other glorious thing among the many we have here in the treasure chest? Then choose but one thing."

For an instant, I was irresolute, then I addressed the gods as follows: "Highly esteemed contemporaries, I choose one thing, that I may always have the laugh on my side." There was not a god that answered a word, but they all burst out laughing. Thereupon, I concluded that my wish was granted, and I found that the gods knew how to express themselves with good taste. 20
}

The gift to accept incongruity is still a gift worth seeking - for ourselves, our families and friends, and for leaders of nations, too. The grace to behold and embrace incongruities and not to run away from them is the beginning of acquiring or preserving the endangered sense of humor.

\section{IV}

In addition to helping us manage incongruity, a sense of humor is also a precondition to holiness. Holiness is about self-discovery and God discovery. For those discoveries to happen, it is necessary to get out of the way, to loosen our grip, to lessen our need to control, and to let God be God.21 A sense of humor helps the sanctification process because it encourages us not to take ourselves too seriously. Taking ourselves too seriously deals a lethal blow to holiness.

It works this way: Leading a life of prayer is about the serious and painful transformation into what (or, more precisely, whom) we love. The target of holiness is precisely the false self which is comfortable on the run, evading the truth, settling for fraudulent and impoverished existence.

Some things happen when we face the truth about ourselves. For one thing, there is no room for pomposity, arrogance, or self- absorption. More than one person has pointed out how closely conjoined "humility" is with "humor." A sense of humor, like a true sense of humility, involves ruthless honesty about who we are, without disguise or pretense. The temptation, of course, is to become weighted with gravity, to deal with prayer and worship with excessive formality, and to take ourselves very seriously indeed. The point is that the opposite route is the direct one. The grace needed is to face ourselves with an appropriate degree of lightness so that we can listen obediently to the plan God has for each of us.

The truth of the matter is that we are singularly gifted in avoiding self-discovery, even though we pay lip service to "letting it all hang out" and "telling it like it is." Impressed with our self-importance and weighted with the seriousness of the adventure of selfdiscovery, we are sitting ducks for missing the meaning of what is going on. So, shock therapy is frequently called for. 
The parables of the New Testament have functioned as shock treatments for centuries, providing insight and revelation about ourselves as unmasked before God. But Thomas Merton (among many others) found in Zen a way of fostering disclosure we too often bypass in the Gospels. Sometimes a different tradition catches us off guard and lets us see what we are skilled at circumventing in the world, a world we are able to manipulate. Thus, Merton tells this story:

A Zen Master said to his disciples: "Go get my rhinoceros horn fan." Disciple: "Sorry, Master, it is broken." Master: "Okay, then get me the rhinoceros." 22

The "lesson" to be learned from this Zen episode is that on the journey of becoming what we were meant to be, we need to let go of preconceived notions, plans, schemes and patterns. We need to suspend logic. A new order of meaning takes over and we need to be humble enough, and have sense of humor enough, to accept that.

On the outside looking in, this exchange is a transparent contest of wills. On the outside looking in, humor abounds. We want to urge the disciple to flow with the event and not to strain against its apparent absurdity. We sense that there are secrets to be learned in such moments. We suspect that the impending enlightenment has to do with the power of God and our capacity for self-deception, which cannot be learned on our own terms, but rather only through the silence, detachment, purity of heart, and indifference which invite God to be present.

But if the wisdom of the Zen approach is apparent to the outsider, it can be painful, frustrating, and stressful to the one on the inside. All of the conventions and rules have been changed. There is no question that a transcendent power, not we, is in charge. Control must be abandoned. Surrender is necessary. Fists holding on tight to preconceptions and "the way we always did it" need to be relaxed.

In the flush of letting go, a death occurs. It is the death of the ego and a death of the familiar, ego-centered order we superimpose on reality. And this is precisely where a sense of humor enters - or, ought to enter - the picture. Without it, we may fearfully retreat into our self-pitying, pompous, or safe selves ready to share the harrowing experience of what almost happened with anyone who will listen. Without a sense of humor, an imprisonment occurs that shackles the human spirit and turns it in on itself in an aggrandized version of its self-importance.

But humor, Peter Berger reminds us, is an affirmation of freedom and an indication that no system or event is able to contain the human spirit. A sense of humor is the saving grace that allows life to emerge from ashes. It is what Berger calls a "signal of transcendence." 23 The moment of enlightenment on the part of the Zen disciple is not only a death, it is also a birth. The "Aha!" of recognition signals a rebirth of ourselves as stronger than we imagined, and more joyful. Here is Merton again on the subject:

"[The true self] is like a very shy wild animal that never appears at all whenever an alien presence is at hand, and comes out only when all is peaceful, ... when he is untroubled and alone. He cannot be 
lured by anyone or anything, because he responds to no lure except that of the divine freedom."24

The freedom Merton talks about is precisely the heart of humor. To be free is to laugh at the false self, the arrogant, puffed-up self, the certain self, the vain self. To be free is to stake everything on God, to risk one's life, to bank on God's promises, because humor relativizes our own importance and restores God to center stage. Humor comes down to this: How deep is our faith and how seriously do we take God's sovereign power? "It relates to the size of your world, to the nature of the stakes on which you are willing to risk your life.... It asks how free you are to serve God with courage, abandon, and a will." 25

Threatened and frightened people will protect all kinds of things - possessions, reputations, status, achievements. But redeemed women and men will count everything as "folly" except service of the Lord. If that doesn't require a sense of humor, nothing I know does.

Humor lets us be free, free at last.

V

There are so many blessings associated with humor that it is hard to imagine a Christian living without this gift. Perhaps that is the point. Anyone who calls himself or herself "Christian" and is without a sense of humor may well be taking the name in vain.

A number of the benefits have to do with physical health. Proverbs 17:22 suggests that "A merry heart does good like a medicine," and several physicians who have done research in this area agree. Physician Raymond A. Moody writes provocatively of the healing effects of humor.26 In some cases of mental illness, especially depression, he holds that humor has been part of the curative process. In innumerable other clinical situations, Dr. Moody holds firmly to the conviction that humor is widely recognized as an important, healthy, and desirable response.

One particularly touching example cited by Dr. Moody is the use of humor by patients who have received disfiguring facial injuries. Humor not only helps these patients to develop an outlook from which their horrendous misfortune seems more bearable, but it also helps them in solving problems in interpersonal communication. Humor defuses tension in such situations and puts everyone at ease. 27

Another American physician, William F. Fry, has studied the effect humor has in producing the alertness hormones, catecholamines.28 These hormones in turn cause the release of endorphins in the brain. Endorphins foster a sense of relaxation and well-being and dull the perception of pain. Catecholamines also enhance blood flow and, thus, may speed healing, reduce inflammation, and stimulate alertness.

For cardiovascular and respiratory functions, the effect of laughter is especially significant. When we laugh, our rhythmic breathing becomes spasmodic and heart rate, blood pressure, and muscular tension increase. When laughter subsides, however, these 
functions often drop temporarily below normal and result in feelings of relaxation which may last as long as forty-five minutes after the last laugh. The preliminary research in this area suggests that laughter may be a powerful weapon in counteracting heart disease and high blood pressure.

Laughter is also associated with the will to live, that crucial attitude that helps people survive all kinds of misfortunes. And while scientific research in this area is still in its early stages, there seems to be a growing sense of appreciation for Mark Twain's observation of the old man who "laughed loud and joyously, shook up the details of his anatomy from head to foot, and ended by saying that such a laugh was money in a man's pocket, because it cut down the doctor's bills like everything." 29

In addition to health, there are other prominent benefits of humor worth mentioning, and it is Shakespeare's Hamlet who best calls them to our attention. Hamlet mourns:

I have of late . . lost all mirth ... it goes so heavily with my disposition that this goodly frame, the earth, seems to me a sterile promontory....

Man delights me not-no, nor woman neither.

(Hamlet, Act II, Scene II)

There is much to learn from Hamlet. For one thing, he points to a crucial benefit of humor, namely, balance. This is a benefit that eludes the Prince of Denmark. There is plenty of sadness, gloom, and misery in his life, but there is little, if any, joy, spontaneity, or fun to offset the heaviness. Balance is a necessary support for healthy living. It means that there is some equality on both the debit and credit sides of the ledger. A balanced person is usually tolerant, with a wide range of tastes, and is not swayed to either extreme.

A second benefit of humor is perspective. About perspective we at least know this: it is possible to keep it, gain it, or lose it. Keeping or gaining perspective is positive. It means that we are reading reality accurately - that we see things as they truly are. Someone who has lost perspective, however, is no longer able to report the world with fairness and objectivity because his or her judgment is impaired.

The gracious gift of humor juggles perspective and coaches us not to be too anxious. Uptightness not only keeps us from "seeing" the humor in a situation, it also obscures God's presence in our lives. It could be that Woody Allen is onto something when he suggests that the secret of the universe is "not to yodel." 30

Third, in upsetting the conventional ways of doing things, humor frees us from ossified forms of behavior, giving us opportunities for creativity. Like prayer, humor deals with surprises that upset the way things are or ought to be. Paul's first letter to the people of Corinth says that "God has chosen the foolish things of the world to confound the wise and the weak things to confound the strong" (1 Cor 1:27-28). That kind of paradoxical behavior fits hand-in-glove with the creativity possible through humor. We reach for new approaches, and they come. Quite simply, in humor, freedom and spontaneity of the person are exalted. 
VI

The divine quality of humor is peeking its fragile head through centuries of humorless Christianity. In the interest of spontaneity and surprise, and in order to strengthen and revitalize one's sense of humor, here are some recommendations:

(1) Retrain the imagination to look for humor. It has possibilities in every situation. Remember that a sense of humor is not the same as laughter or telling jokes.31 The world is filled with people who tell jokes - mostly at the expense of others - but who have no sense of humor. Decide that you will not be one of them.

(2) Take inventory of a situation causing pain. How could it be approached or resolved differently if a sense of humor were operative? If you don't know where to begin, seek out the advice of someone who is joyful and gifted with a sense of humor. Re- member that humor lightens the heaviness associated with hurt. Humor doesn't deny the hurt; it is the vehicle through which anger and defiance and pain are handled. Peter Berger writes, "By laughing at the imprisonment of the human spirit, humor implies that the imprisonment is not final but will be overcome." 32

(3) Spend time with people who have a sense of humor. Their perspective will be contagious. Spend time with people who know how to laugh at themselves. Anyone can laugh at another's stupidity; it takes a special gift of self-awareness and selfconsciousness to recognize folly in ourselves.

(4) Do not yield the conviction that an alliance exists between laughter and communication with God. American novelist Frederick Buechner traces his interest in religion to a sermon by George Buttrick in which Buttrick proclaimed that Christ is crowned in the hearts of believers "among confession and tears and great laughter." It was the phrase "great laughter" Buechner says, that caught his attention and held it.33

(5) Use laughter to deflect an "attack," to ease the stress of feeling on the defensive. The ancient art of akido, one of the forms of Eastern martial arts, invites blending with your opponent rather than defeating him or her. Akido prohibits aggression and asks for a graceful response to potential insult or injury. So does akido's modern equivalent, "tongue fu." ${ }_{34}$ For example, when the humorist Robert Benchley asked a uniformed gentleman outside a restaurant to hail a cab for him, the man was indignant. "Do you realize you are speaking to a rear admiral in the United States Navy?" Mr. Benchley's swift reply: "O.K., then, get me a battleship." This exercise scales down opposition and lets us flow with events with serenity.

(6) Take a five-to-ten-minute laugh break every day. Why not? We already are accustomed to taking refreshment breaks, and there is general consensus that humor is refreshing. A place to begin might be by reading one of the books connected with the humor of Pope John XXIII. It was he who once wryly reminisced that there are three sure-fire ways to lose money - carousing, gam- bling, and farming - and that his own father had chosen the most boring route. 35 
(7) Find, and then celebrate, humorous insights among theologians and clergy to encourage more of this activity among those groups. Humor is often present, though undetected. It is undetected because it is unexpected. For example, Jonathan Ed- wards often poked fun at Christians who could not find tinny, inauthentic sounds in their ardent but otherwise boring prayers to the Almighty. Edwards wrote: "A person may be overfull of talk of his own experiences; commonly falling upon it, every- where, and in all companies; and when it is so, it is rather a dark sign than a good one. As a tree that is overfull of leaves seldom bears much fruit; and as a cloud, though to appearance very pregnant and full of water, if it brings with it overmuch wind, seldom affords much rain to the dry and thirsty earth." 36

(8) Practice laughing. Psalm 2 says that God laughed, and on the principle that what God does must be good for us, too, look for occasions to laugh and then $d o$ it, even if it takes a little push. We know that laughter loosens up the diaphragm, which is in contact with all the other vital organs of the body. When we laugh, all these organs are massaged. It could be that our spirits get massaged, too. It is important to know the difference be- tween phony laughter and the real kind. Czech novelist Milan Kundera notes that "the devil laughs because God's world seems senseless to him; the angel laughs with joy because everything in God's world has meaning." 37

(9) The last suggestion may be the most important of all: Look for humor in the Scriptures. The Old and New Testaments literally brim with humor we often overlook because of patterns of conditioning that are hard to break. Be prepared to be surprised. Relax. Loosen the controls. Read the Bible, open to the possibility that something new is happening - that God lives in laughter, lightness, freedom, spontaneity, and some unfamiliar places.

And refuse to believe anyone who tells you otherwise.

Notes

*G. K. Chesterton, Lunacy and Letters, edited by Dorothy Collins (New York: Sheed and Ward, 1958), p. 97.

2 See Conrad Hyers, "Easter Hilarity," in And God Created Laughter: The Bible as Divine Comedy (Atlanta: John Knox Press, 1987), pp. 24-28.

3 Umberto Eco, The Name of the Rose (New York: Harcourt, Brace, Jovanovich, 1983), p. 474. Jorge suggests that laughter is the devil's strategy to loosen our guard: "Laughter frees the villain from fear of the Devil, because in the feast of fools the Devil also appears poor and foolish, and therefore controllable." C. S. Lewis also saw a connection between laughter and the devil, although he approached the subject in a way different from Eco. In The Screwtape Letters, Lewis proposed that Christianity without laughter was the devil's doing. Thus, for the mischievous devils, Screwtape and Wormwood, to do their work, "laughter should be discouraged." So, too, must fun and joy be eliminated because they promoted "undesirable tendencie" from the devil's point of view, like "charity, courage, contentment, and many other evils." Cf. The Screwtape Letters (New York: Macmillan paperback edition, 1974), p. 50.

4 The Name of the Rose, p. 471.

5 Reinhold Niebuhr, "Humour and Faith," in Discerning the Signs of the Times (New York: Charles Scribner's Sons, 1946), p. 111.

6 The source for this story is "Meditations on a Joyful Year, Speed Vogel Talks with Moshe Waldoks," in Parabola, XII (4) 1987, p. 63. 
7 Stanley M. Handleman, "From the Sublime to the Ridiculous: The Religion of Humor," in Handbook of Humor Research, edited by Paul E. McGhee and Jeffrey H. Goldstein, (New York: Springer-Verlag, 1983), p. 27.

8 Particularly helpful is the work of John Dominic Crossan, especially In Parables: The Challenge of the Historical Jesus (San Francisco: Harper and Row, 1973); Raid on the Articulate: Comic Eschatology in Jesus and Borges (San Francisco: Harper and Row, 1976); and The Dark Interval: Towards a Theology of Story (Allen, TX: Argus/DLM Communications, 1975). See also Dan O. Via, Kerygma and Comedy in the New Testament (Philadelphia: Fortress Press, 1975). Of particular pastoral interest is Michael Moynahan's Once Upon a Parable: Story Dramatizations of Jesus' Parables of the Kingdom of God (Mahwah, NJ: Paulist Press, 1984) and the creative application of scholarship by Doug Adams in "Bringing Biblical Humor to Life in Liturgy," Modern Liturgy (Vol. 6, No. 8) and "Informing Liturgies with Jesus' Parables," Modern Liturgy (May, 1981).

9 Robert Fowler, Loaves and Fishes: The Function of the Feeding Stories in the Gospel of Mark (New York: Scholars Press, 1981).

10 Mary Douglas, "The Social Control of Cognition: Some Factors in Joke Perception," Man (III, 1968), p. 365.

11 Jonathan Z. Smith, "Good News Is No News: Aretology and Gospel," in Christianity and Judaism and Other Greco-Roman Cults: Studies for Morton Smith at Sixty, edited by Jacob Neusner (Leiden: F. J. Brill, 1975).

12 Gerald A. Arbuckle coins this phrase in his book, Strategies for Growth in Religious Life (New York: Alba House Publications, 1986), pp. 75ff. In this connection, see also Robert E. Neale, "Surprise: The Horrible, the Humorous and the Holy," in New Dimensions in Religious Experience (New York: Alba House Publications, 1971), pp. 36-37, where he talks of the event of the incarnation as "the incarnation of the Complete Humorist. In Christ there was no anxiety. Although his life was serious, He did not live seriously. That is, he did not work for survival as we do. What surprised him, humored him."

13 See Doug Adams, "Bringing Biblical Humor to Life in Liturgy," p. 4.

14 Robert Funk's insight is quoted in the Adams article, p. 5.

15 A fine thematic weaving of this definition is presented by Helen M. Luke, "Laughter at the Heart of Things," in Parabola, Vol. XII, No. 4 (1987), pp. 1-17, especially pp. 6-8.

16 See Gary Commins, "Woody Allen's Theological Imagination," THEOLOGY TODAY, Vol. XLIV, No. 2 (1987), pp. 235-249, especially pp. 235 and 243. Commins suggests that Allen extends the rabbinic tradition of arguing with God to arguing with the idea of God. He finds in Allen a reminder of the limits of human understanding and an awareness of the paradox that revelation and hiddenness are often partners. Of Allen's sense of humor, Commins concludes: "Perhaps the power of redemption, the power to liberate, comes not from Zeus descending onto the stage to intervene but through the power of love that enters into the world in vulnerability" (p. 249).

17 Reinhold Niebuhr, "Humour and Faith," p. 126.

18 On this subject, cf. Maria Harris, "Religious Educators and the Comic Vision," in Religious Education 75 (July-August, 1980), pp. 422-432, where she writes: "Asserting the comic is also a denial of the primacy of evidence and demonstrable fact. When sin and suffering and evil and poverty abound, a reasonable and rational conclusion can certainly be drawn in favor of despair. In this instance, the Comic Vision testifies not to the presence of what is seen, but to the as yet unknown or unproven."

19 Karl Rahner, S. J., "Current Problems in Christology," in Theological Investigations, I, translated by Cornelius Ernst (Baltimore: Herder and Herder, 1961), pp. 149-200.

20 Cited in D. T. Suzuki and E. Van Hoboken, Sengai (Greenwich, Conn.: New York Graphic Society, 1971), p. 6.

21 On the subject of control, Sigmund Freud and the philosopher Henri Bergson are in agreement. Both hold humor to be the breakdown of control. For Freud, the joke or the humorous situation provided the opportunity for relaxation of the conscious control in favor of the subconscious. Bergson and Freud saw humor as an attack on routine and the predictable. See Henri Bergson, "Laughter," in Comedy, edited by W. Sypher (Baltimore: Johns Hopkins University Press, 1956), pp. 61-190, and Sigmund Freud, Jokes and Their Relation to the Unconscious, translated by J. Strachey (New York: W. W. Norton, 1983), pp. 144158.

22 Thomas Merton, Zen and the Birds of Appetite (New York: New Directions, 1968), pp.13-14.

23 Peter Berger, A Rumor of Angels (New York: Doubleday, 1969), p. 88. See also his The Precarious Vision (Westport, CT: Greenwood Press, 1961; reissued, 1981); pp. $209 \mathrm{ff}$. 
24 "The Inner Experience: Notes on Contemplation," (an unpublished manuscript) quoted in James Finley, Merton's Palace of Nowhere (Notre Dame, Ind.: Ave Maria Press, 1978), p. 91.

25 James I. McCord, "On Getting and Keeping a Sense of Humor: Farewell Remarks to the Graduating Class of 1973," in Princeton Seminary Bulletin, 67 (Winter, 1975), p. 49.

26 Raymond A. Moody, Jr., M.D., Laugh after Laugh: The Healing Power of Humor (Jacksonville, Fla.: Headwaters Press, 1987).

27 Ibid., pp. 25-26.

28 The reporting about Dr. Fry and the beneficial effects of laughter on cardiovascular and respiratory patients comes from the "Personal Health" column of Jane E. Brody in The New York Times, National Edition, April 7,1988, p. 18.

29 Mark Twain, The Adventures of Tom Sawyer (New York: Modern Library edition, 1940), p. 208.

30 Woody Allen, "Fabulous Tales and Mythical Beasts," in Without Feathers (New York: Random House, 1975), p. 181

31 C. S. Lewis distinguishes the causes of human laughter as joy, fun, the joke proper, and flippancy. Cf. The Screwtape Letters, pp. 50-52.

32 Peter Berger, A Rumor of Angels, p. 88.

33 Frederick Buechner, The Sacred Journey, (New York: Walker \& Co., 1984), p. 109.

34 Jane E. Brody, op. cit.

35 A Pope Laughs: Stories of John XXIII, collected by Kurt Klinger (New York: Holt, Rinehart and Winston, 1964), p. 110.

36 Jonathan Edwards, Religious Affections, edited by John E. Smith (New Haven: Yale University Press, 1959), p. 137.

37 This comment is made by Kundera in The Book of Laughter and Forgetting, p. 232. Kundera continues: "Two lovers race through the meadow, holding hands, laughing. Their laughter ... is the serious laughter of angels expressing their joy of being" (New York: Penguin, 1981) (p. 233; his italics). Note also, the titles of two of Kundera's other books: The Joke and Laughable Loves. 